many samples varying so widely in quality, even though taken from the same cat or lot of coal, the most common fault being that the original samples taken have been too small. The absolute necessity of taking large samples will lead to mechanical or automatic sampling in many places.

Io. The chances of error in the chemical analysis are insignificant when compared with the errors in the existing methods of sampling coal. The chemist should be responsible for the sampling in every possible instance.

II. Almost every one who has given any consideration to the sampling of coal or other similar material, has said that a large sample should be taken and that it should be broken or crushed fine before the successive quarterings. How large, and how fine, have been left to the judgment of the individual taking the sample, and it is the object of this paper to answer these questions with some degree of accuracy. As this data is of a preliminary nature, it is hoped that others will not only verify these results, but add to them, in order that the sampling of coal and other material may be reduced to a more scientific basis.

\section{THE COMMERCIAL MANUFACTURE OF AMORPHOUS CALCIUM PHOSPHIDE.}

By CaArles E. Munroe.

Received January 8, 1909.

In I89I, I was directed to prepare calcium phosphide on a limited commercial scale. The Howell Automobile Torpedo had then been developed to such an extent that it had been tentatively accepted as a service weapon, and officers and seamen gunners of the Navy were being trained, by target practice, to become skilled in its use. As devised, this torpedo was so constructed that, as ready for service, it would, when stationary or running at low speed, fill with water to such an extent as to sink the torpedo and drown its priming charge and detonator so as to render them harmless, for, if in action a live torpedo failed to hit the enemy at which it was aimed and became vagrant, it would prove a menace to friend as well as foe. Although, in target practice, the war heads were not used it was necessary that otherwise the torpedo should be arranged and should operate as in action. But the sinking of the torpedoes at the end of their runs was, owing to the difficulty of locating them in deep water, a serious impediment to practice, as they were expensive. Hence, it was most desirable to recover them. Various devices were invented with the object of surmounting this difficulty. The one which proved most efficient was the inserting in the nose of the torpedo of a can of calcium phosphide, with holes punctured in the top of the can, for as the torpedo took the water the reaction of the phosphide with the water entering the can gave rise to a cloud of smoke, which was visible by day, and a faintly luminous flame, which was visible by night, and these phenomena enabled one not only to easily follow the course of the torpedo during its run but also to locate it with great accuracy after it had sunk. It thus became easily possible to recover the torpedo by grappling.

As there was, previous to the erection of this furnace, no manufacture, so far as was known, of calcium phosphide in this country, it was imported from Europe at a cost of $\$ 2.25$ per pound. Quite apart from the high cost a difficulty was met in importing it, owing to the custom's officers, who insisted on breaking open the sealed packages and inspecting their contents greatly to the disgust of both the inspecting officers and the importers, though for different reasons, and to the damage of the material. For these various reasons, I was directed to manufacture it and the material was then supplied by the Government to the company furnishing the torpedoes.

From the literature it was learned that Dumas ${ }^{1}$ placed fragments of quicklime in a retort set horizontally on a grate and disposed phosphorus at the extremity of the neck, which was closed with a stopper. When the lime had been heated to redness the phosphorus was passed over it in the state of a vapor, thus producing calcium phosphide.

Thenard ${ }^{2}$ made use of a clay crucible, of about I liter capacity, pierced at the bottom by a hole I to $2 \mathrm{~cm}$. in diameter. The neck of a glass flask, of about $250 \mathrm{cc}$. capacity was passed through the hole in the bottom of the crucible and luted in place, and the whole arranged in a furnace with a double grate so that the flask hung suspended above the lower grate. The flask was filled with phosphorus and the crucible above it with quicklime. When the lime had been heated to redness, heat was applied to the glass flask and thus the vapors of the phosphorus were passed through and about the lime. The operation lasted 30 to 40 minutes and about 500 to 600 grams of the phosphide were obtained.

\footnotetext{
1 Ans. Chim. Phys. [2], 33, 363 (1826).

2 Ibid. [4], 14, 12 (1845).
} 
A preferred form of crucible recommended by Thenard, was one which was divided into two parts by an earthenware grid, the lower section, about $\mathrm{I} / 3$ to $\mathrm{I} / 4$ the height of the crucible, being used to hold the phosphorus. Such a crucible is pictured by Pelouze et Fremy ${ }^{1}$ but they effected the division by placing a small crucible inside the large one and placing the grid on the small one. However, they continued the use of a furnace with two grates.

Gattermann and Haussknect ${ }^{2}$ made use of a covered Hessian crucible, resting on the grate of a crucible furnace, in which to put the lime, and when the latter had been brought to a glow, they dropped in sticks of phosphorus by means of a vertical iron tube which passed through the covers of the furnace and crucible, and reached to within $2 \mathrm{~cm}$. of the bottom of the crucible, the upper end of the iron tube having a glass tube fitted into it by means of an asbestos packing. ${ }^{3}$ They used about 500 grams of lime and added to it 350 to 400 grams of phosphorus.

This was the state of the art as I found it at the time of beginning this work. Experiments were made with glass and earthenware vessels, but they proved unsatisfactory. Tests were then made with an iron tube, butt-welded at one end, and this resisted the action of molten and vaporized phosphorus so well that crucibles were made from 5 inch wrought iron tubes with welded bottoms, their dimensions being as follows: depth inside 6 inches, outside 7 inches, diameter at top, inside 5 inches, outside $55 / 7$ inches. They were provided with grooved lids, $\mathrm{r} / 4$ inch thick and 6 inches outside diameter, which were fitted with asbestos gaskets. A slotted lug was welded on each side of each crucible and a wedge-shaped iron key was provided so that by driving it through the slots the cover of a crucible was easily fastened on tightly and firmly. Through one side of the cover a wrought iron pipe, $I 2$ inches long, and $I$ inch in diameter, was swedged, the lower end of the pipe being flush with the inside face of the crucible cover. This pipe was provided with a cap 4 inches long and I I/4 inches inside diameter. Three of these pots are shown in the photograph. They held about 1500 grams of lime each. They were heated with coal in an ordinary square crucible furnace.

1 Traite de chimie, 2, 558 (1865).

2 Berichte, page 1175 (1890).

3 This apparatus, except for the glass extension tube, is practically identical with that of $M$. Silas shown in Memoires Militaires et Scientifique, 5 [XXXII], pp. 9, 1877.
The lime used was "black marble lime, woodburned." It was of high quality and it was broken into lumps I to I $\mathrm{I} / 2$ inches in diameter. The crucible was charged with the lime, the cover put on and keyed, and the whole lifted by the feed pipe and embedded in the fire in the furnace. When the crucible had become heated to between a dark and cherry redness the cap was lifted from the feed pipe, sticks of dry phosphorus were dropped in and the cap replaced. So soon as fuming ceased, which with the right proportion of phosphorus was almost immediately, the crucible was lifted from the furnace and allowed to cool with the cap on so as to prevent air from reaching the phosphide in any considerable volume during the cooling process. The operation required about $1 / 2$ hour. With I 400 grams of lime to the pot and 200 grams of phosphorus added about 1600 grams of phosphide were obtained. With a larger quantity of phosphorus the yield was no greater as the excess of phosphorus fumed off. Using four pots, an unskilled workman, after short practice, turned out 28 pounds per short day. The cost, counting labor and materials, was 20 cents per pound. The same pots were used, without repairs, for some eight years.

The phosphide produced in this way was very active, giving off spontaneously inflammable hydrogen phosphide promptly on contact with water. A perforated tin container holding a pound of this amorphous calcium phosphide, when submerged in 18 feet of sea water, gave a flame, which rose some two feet above the surface of the water, and voluminous smoke, and it continued intermittently to give off flame and smoke for over five hours. It was found to be more satisfactory in its behavior than the imported article. Portions of it made 17 years ago seem to-day to be as active as when freshly manufactured.

Since this work was accomplished, H. Moissan ${ }^{1}$ has obtained calcium phosphide by reducing tricalcium phosphate with carbon in an electric furnace, and also by the action of phosphorus on metallic calcium. The product thus obtained was crystalline and it reacted with water to produce phosphine $\left(\mathrm{H}_{3} \mathrm{P}\right)$, which was not spontaneously inflammable, while the product obtained by the action of phosphorus on lime, after the manner described above, is amorphous and reacts with water to produce hydraphosphine $\left(\mathrm{H}_{4} \mathrm{P}_{2}\right)$, to which is attributed its property of generating a spon-

1 Compies rendus, 128, 787 (1898). 
taneously inflammable product. E. Renault ${ }^{1}$ has also obtained the crystalline calcium phosphide in the electric furnace, carrying out the operation in both iron and carbon crucibles, but he states that under certain circumstances he obtained, from the tricalcium phosphate, a phosphide which yielded both $\mathrm{H}_{3} \mathrm{P}$ and $\mathrm{H}_{4} \mathrm{P}_{2}$. This is quite to be expected for I recall that when operating the plant at Spray, N. C., in 1895 , for the production of calcium carbide I noted the presence of calcium phosphide in the product, due to reduction of itself for its simplicity, low cost of installation, the wide accessibility of the apparatus and materials used, and the ease with which it can be carried out by unskilled labor.

With this manufacture in successful operation in the Navy there was naturally a desire to further utilize the product in the solution of other naval problems. It had then been recognized that the electric search lights installed in the Navy were not an unmixed blessing for while they might be used in locating the enemy they never failed

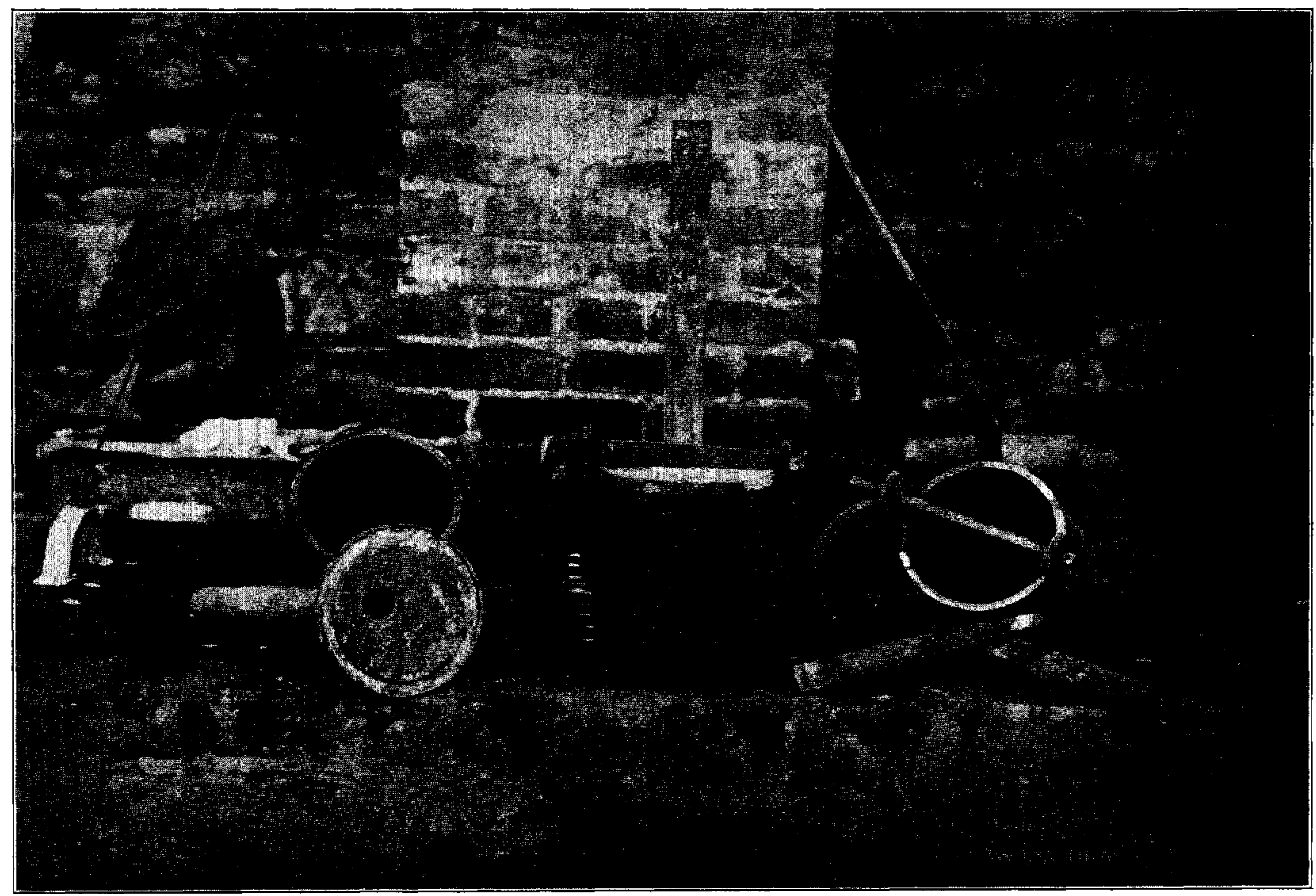

calcium phosphate in the lime, and I attributed the spontaneous inflammation of the acetylene, and other gases, produced by the reaction of the carbide with water, to the simultaneous formation of hydraphosphine.

No doubt if there were any considerable demand for amorphous calcium phosphide it could be most economically met by electric furnace methods, but as the uses for this material are limited the method I have described is sufficient and commends

1 Comptes rendus, 128, 883-884 (1898). also when in use to locate the vessel that carried them, and therefore they failed in enabling one to take the enemy by surprise. It was evident that this defect could be remedied by means of a self-igniting light which could be thrown, say in a shell from a gun, among the enemy. With this in view, experiments were made with the product from this furnace but though perfectly clear, yet quite dark, nights were chosen for the tests, when the vessels in the harbor were at anchor with some of their sails spread, and the seamen 
gunners who laid the test shells were clad in white duck working suits, yet the intrinsic luminosity of the phosphide flame was so slight that no useful result was obtained. Quite recently, however, according to reports, this result has been successfully accomplished and we find in calcium carbide, mixed with calcium phosphide, a material which, when thrown to a distance, will, when alighting in water, produce a self-igniting flame which has a high intrinsic illuminating power.

i But the economic use to which this material has been longest put and even to-day, probably, the chief use to which it is put, is as an attachment to life-saving emergency buoys which are carried aboard passenger vessels in locations from which they may be readily thrown at the call of "Man Overboard," for though the flame given by the phosphide is dim yet it is often sufficient to enable the person struggling in the water to locate the buoy. This application is described in great detail in De l'application de phosphure de calcium a l'appareil éclairant des bouces de sauvetage, ${ }^{1}$ and it therefore will not be enlarged upon here.

The GeORGE WASHINGTON UNIVERSity.

\section{THE TEMPERATURE OF THE LEAD BUTTON IN CUPELLATION.}

By Robert H. Bradford, Ph.D., Prof, of Metallurgy, State School of Mines, University of Utah.

Received December 24, 1908.

Excellent work with the assay furnace was done by early investigators. They had no means of ascertaining exact temperatures, and hence in their writings they attempt to describe the desired temperatures by the appearance of the objects to the eye, using such color terms as would most nearly apply to the degree of heat under consideration. They recognized the importance of employing proper muffle temperatures in cupellation, as is indicated by the following careful description of the same given by an early text-book on assaying:" "When the interior of the muffle is reddish white the matters to be cupelled may be introduced. When the cupels are filled, the furnace is closed, either by the door or by pieces of lighted fuel, so that the fused metals may become of the same temperature as the muffle. When this point has been gained, air is allowed to pass into the furnace; the metallic bath is then in the state

${ }^{1}$ Mémoires Militaires et Scientifiques, 1878, XXXII.

"John Mitchell: "Manual of Practical Assaying," 2nd edition, p. 368-370 (1868). termed 'uncovered;' that is, it presents a convex surface, very smooth, and without slag. When the air comes in contact with it, it becomes very lustrous, and is covered with luminous and iridescent patches, which move on the surface, and are thrown toward the sides. These spots are occasioned by the fused oxide of lead which is continually forming, and which, covering the bath with a very thin coating of variable thickness, presents the phenomenon of colored rings.

"As silver is sensibly volatile, it is essential, in order that the smallest possible quantity be lost, to make the cupellation at as low a temperature as may be. On the other hand, the heat ought to be sufficiently great, so that the litharge may be well fused and absorbed by the cupel.

"Experience has proved that the heat is too great when the cupels are whitish, and the metallic matter they contain can scarcely be seen, and when the fume is scarcely visible and rises rapidly to the arch of the muffe. On the contrary, the heat is not strong enough when the smoke is thick and heavy, falling in the muffle, and when the litharge can be seen not liquid enough to be absorbed, forming lumps and scales about the assay. When the degree of heat is suitable the cupel is red, and the fused metal very luminous and clear."

Modern texts are less elaborate in their descriptions, yet they lay especial stress on the importance of maintaining proper temperatures in the assay muffle.

The modern pyrometer, for accurately measuring high temperatures, has recently come to fill a long-felt want in many metallurgical operations. Since the need of employing definite temperatures in assaying is generally recognized, one would expect that the pyrometer would be employed more commonly in the muffle, and greater accuracy observed in stating degrees of temperature. It is gratifying to see some recent magazine articles and texts on assaying employing exact figures for representing temperatures required for the various operations in the furnace.

It is difficult to reconcile some explanations of cupellation phenomena, based on pyrometer readings, with certain well established facts. The lack of sufficient exact data may account for some apparent discrepancies, as the following instance will show. One very recent manual of assaying ${ }^{1}$ in describing the process of cupellation says: "Little flakes of $\mathrm{PbO}$ form on the surface of the

1 C. H. Fuiton: "Manual of Fire Assaying," 1907, pages 70, 71. 